\title{
INTEGRASI NILAI KARAKTER DALAM PRAKTIK PEMESINAN FRAIS MELALUI MODEL PEMBELAJARAN COMPETENCE BASED TRAINING
}

\author{
Paryanto $^{1}$, Bambang Setiyo Hari Purwoko ${ }^{2}$, Edy Purnomo ${ }^{3}$ \\ 1,2,3, Jurusan Pendidikan Teknik Mesin FT UNY \\ Email: paryanto@uny.ac.id
}

\begin{abstract}
The purpose of this study is to find out the differences in students' activity and academic achievement on the implementation of character-based Competence Based Training (CBT) learning model. The research used two groups Quasi Experimental Design. Samples were taken by cluster sampling, in which one class of bachelor degree students was used as control group and one class of diploma degree students as experimental group. Data were collected using observation technique with instruments of attitude, behavior and products. Data were analyzed using quantitative descriptive analysis with t-test. Result shows that there are differences in students' learning activities and academic achievement on Milling Machining practice using character-based CBT, in which the learning activity and achievement of the experimental class are better than the control class.
\end{abstract}

Keywords: integration, character value, milling machine, competence based training

\begin{abstract}
ABSTRAK
Tujuan penelitian ini adalah untuk mengetahui bagaimana perbedaan aktivitas dan prestasi belajar mahasiswa antara kelas yang menerapkan model pembelajaran CBT berbasis karakter dengan kelas yang tidak menerapkan. Desain penelitian yang digunakan adalah desain Quasi Experimental Design dua kelompok. Sampel penelitian diambil secara Cluster Sampling, yaitu untuk program S1 diambil 1 kelas sebagai kelas kontrol dan program D3 diambil 1 kelas sebagai kelas eksperimen. Pengumpulan data menggunakan teknik observasi dengan instrumen sikap, perilaku dan produk. Analisis data menggunakan teknik analisis deskriptif kuantitatif dengan t-test. Hasil penelitian menunjukan terdapat perbedaan aktivitas belajar mahasiswa dalam pembelajaran praktik Pemesinan Frais melalui penerapan model pembelajaran CBT berbasis karakter, dimana aktivitas belajar mahasiswa pada kelas eksperimen lebih baik dari kelas kontrol. Terdapat perbedaan prestasi belajar mahasiswa dalam pembelajaran praktik Pemesinan Frais melalui penerapan model pembelajaran CBT berbasis karakter, dimana prestasi belajar pada kelas eksperimen lebih baik dari kelas kontrol.
\end{abstract}

Kata kunci: integrasi, nilai karakter, pemesinan frais, competence based training

\section{PENDAHULUAN}

Undang-Undang Pendidikan Nasional No. 20 Pasal 3 Tahun 2003, menyatakan bahwa pendidikan nasional harus mengembangkan kemampuan dan membentuk karakter serta peradaban bangsa yang bermartabat dalam rangka mencerdaskan kehidupan bangsa, bertujuan untuk berkembangnya potensi peserta didik agar menjadi manusia yang beriman dan bertakwa kepada Tuhan Yang Maha Esa, berakhlak mulia, sehat, berilmu, cakap, kreatif, mandiri,dan menjadi warga negara yang demokratis serta bertanggung jawab.

Pendidikan vokasional sebagai bagian dari sistem pendidikan nasional memainkan peran yang sangat strategis bagi terwujudnya tenaga kerja yang terampil dan berkarakter. Suyanto (2010) menyatakan bahwa dalam era globalisasi, peluang untuk memiliki pertumbuhan ekonomi yang tinggi dan berkelanjutan dari suatu negara akan semakin besar jika didukung oleh SDM yang memiliki: 
(1) pengetahuan dan kemampuan dasar untuk menyesuaikan diri dengan tuntutan dan dinamika pembangunan yang tengah berlangsung; (2) karakter yang unggul, beriman dan bertakwa kepada Tuhan Yang Maha Esa; (3) jenjang pendidikan yang semakin tinggi; (4) keterampilan keahlian yang berlatarbelakang ilmu pengetahuan dan teknologi (iptek); dan (5) kemampuan untuk menghasilkan produk-produk yang unggul, baik dari kualitas maupun harga, mampu bersaing dengan produk-produk lainnya di pasar global. Data Badan Statistik Nasional (BPS) tahun 2014, terdapat 81,1 juta tenaga kerja Indonesia diisi kelompok unskill workers (pekerja yang tidak punya skill atau kompetensi di bidangnya). Kelompok unskill workers ini mayoritas adalah lulusan sekolah umum. Sedangkan kelompok di atasnya diisi skill workers (pekerja dengan skill atau kompetensi dibidangnya) sebesar 20,4 juta orang. Serta komposisi teratas merupakan pekerja expert (ahli) dengan 4,8 juta orang. Melihat kondisi seperti ini Indonesia akan sulit bersaing dengan negara lain dalam era globalisasi dan kompetisi yang ketat.

Sementara itu, dunia pendidikan di negara kita akhir-akhir ini menjadi terpuruk oleh fenomena kurang menggembirakan yang terlihat dari banyaknya terjadi tawuran pelajar, pergaulan a-susila dikalangan pelajar dan mahasiswa, pornografi, penggunaan narkoba, mencari kehidupan non-science dengan memuja kekuatan gaib, mencari jawaban dari paranormal, menyelami black-magic dan mempercayai mistik. Diperparah oleh pengaruh budaya barat berbentuk sensateculture dan gaya hidup konsumeristis, rakus, boros, cinta mode, pergaulan bebas, individualistik, kebebasan salah arah, lepas dari nilai-nilai agama dan adat luhur.

Fenomena negatif tersebut juga dirasakan terjadi di Jurusan Pendidikan Teknik Mesin FT UNY, khususnya yang terjadi dalam proses pembelajaran praktik pemesinan secara keseluruhan. Dalam proses pembelajaran praktik, sikap mahasiswa jauh dari yang semestinya dijalankan. Masih banyak dijumpai mahasiswa yang kurang disiplin, yaitu sering datang terlambat dan dalam bekerja tidak sesuai dengan prosedur yang benar. Seringkali mahasiswa meninggalkan ruang praktik pada saat pembelajaran sedang berlangsung. Kepedulian mereka terhadap kebersihan lingkungan maupun perawatan alat dan mesin yang mereka gunakan selama praktik juga sangat kurang, sehingga beberapa komponen mesin dan peralatan sudah mengalami kerusakan. Sifat teliti dan ketelatenan mahasiswa masih sangat kurang, hal ini terlihat jelas dari benda kerja hasil praktik memiliki dimensi yang menyimpang jauh dari yang semestinya.

Disamping beberapa hal tersebut, kemampuan akademis mahasiswa ternyata 75\% masih termasuk dalam kategori rendah. Hal ini dapat dilihat pada saat penyusunan Work Preparation Sheet, mereka mengalami kesulitan dalam penentuan parameter pemotongan setiap job yang harus mereka kerjakan. Disamping itu, akhir-akhir ini mahasiswa kurang memiliki rasa hormat kepada dosen, seringkali mahasiswa bersikap tidak sopan terhadap dosen.

Berdasarkan kenyataan tersebut, menjadi tanggung jawab dunia pendidikan khususnya pendidikan vokasional tak terkecuali bagi Jurusan Pendidikan Teknik Mesin FT UNY, untuk menciptakan lulusan yang selain memiliki kompetensi akademik juga berkarakter unggul. Oleh karena itu menjadi keharusan untuk mengintegrasikan nilai-nilai karakter dalam proses pembelajaran, tak terkecuali dalam pembelajaran Praktik Pemesinan Frais. Salah satu upaya untuk mengintegrasikan nilai-nilai karakter dalam pembelajaran Praktik Pemesinan Frais adalah dengan menerapkan model pembelajaran Competence Based Training (CBT) berbasis karakter.

Model pembelajaran Competence Based Training (CBT) berbasis karakter merupakan model pembelajaran yang telah dikembangkan oleh peneliti (Paryanto, dkk: 2013). Dalam 
model pembelajaran ini sekaligus menyisipkan nilai-nilai karakter ke dalam proses pembelajaran yang sedang dijalankan. Sehingga dengan menerapkan model pembelajaran Competence Based Training (CBT) berbasis karakter ini diharapkan mampu membekali mahasiswa dengan kompetensi akademik serta sekaligus membentuk karakter mahasiswa yaitu disiplin, teliti, percaya diri, komunikasi, mampu bekerjasama dalam tim, serta memiliki daya analisis yang kuat.

Pembelajaran berbasis kompetensi adalah pembelajaran yang dilakukan dengan orientasi pencapaian kompetensi peserta didik (Gonczi, 1998: 45). Sehingga muara akhir hasil proses pembelajaran adalah meningkatnya kompetensi peserta didik yang dapat diukur pada sikap, pengetahuan, dan keterampilan (Sidik Purnomo: http://kidispur.blogspot.com). Konsep pembelajaran berbasis kompetensi mensyaratkan dirumuskannya secara jelas kompetensi yang harus dimiliki atau ditampilkan peserta didik setelah mengikuti kegiatan pembelajaran. Dengan tolok ukur pencapaian kompetensi maka dalam kegiatan pembelajaran peserta didik akan terhindar dari mempelajari materi yang tidak perlu yaitu materi yang tidak menunjang tercapainya penguasaan kompetensi (Mulyasa, 2006: 56).

Model pembelajaran CBT berbasis karakter merupakan hasil pengembangan model pembelajaran yang telah dilaksanakan oleh peneliti (Paryanto, dkk: 2013) pada penelitian sebelumnya. Dalam model pembelajaran ini, dikembangkan dari model pembelajaran CBT, dimana dalam proses pembelajarannya dimodifikasi sedemikian rupa sehingga mampu menanamkan aspek atau nilai-nilai karakter kepada mahasiswa. Sehingga dengan dilaksanakannya model pembelajaran ini, disamping mampu membekali mahasiswa dengan kompetensi akademik juga mampu membentuk karakter mahasiswa yang unggul. Tahapan dalam model pembelajaran CBT berbasis karakter dapat dilihat dalam Gambar 1.

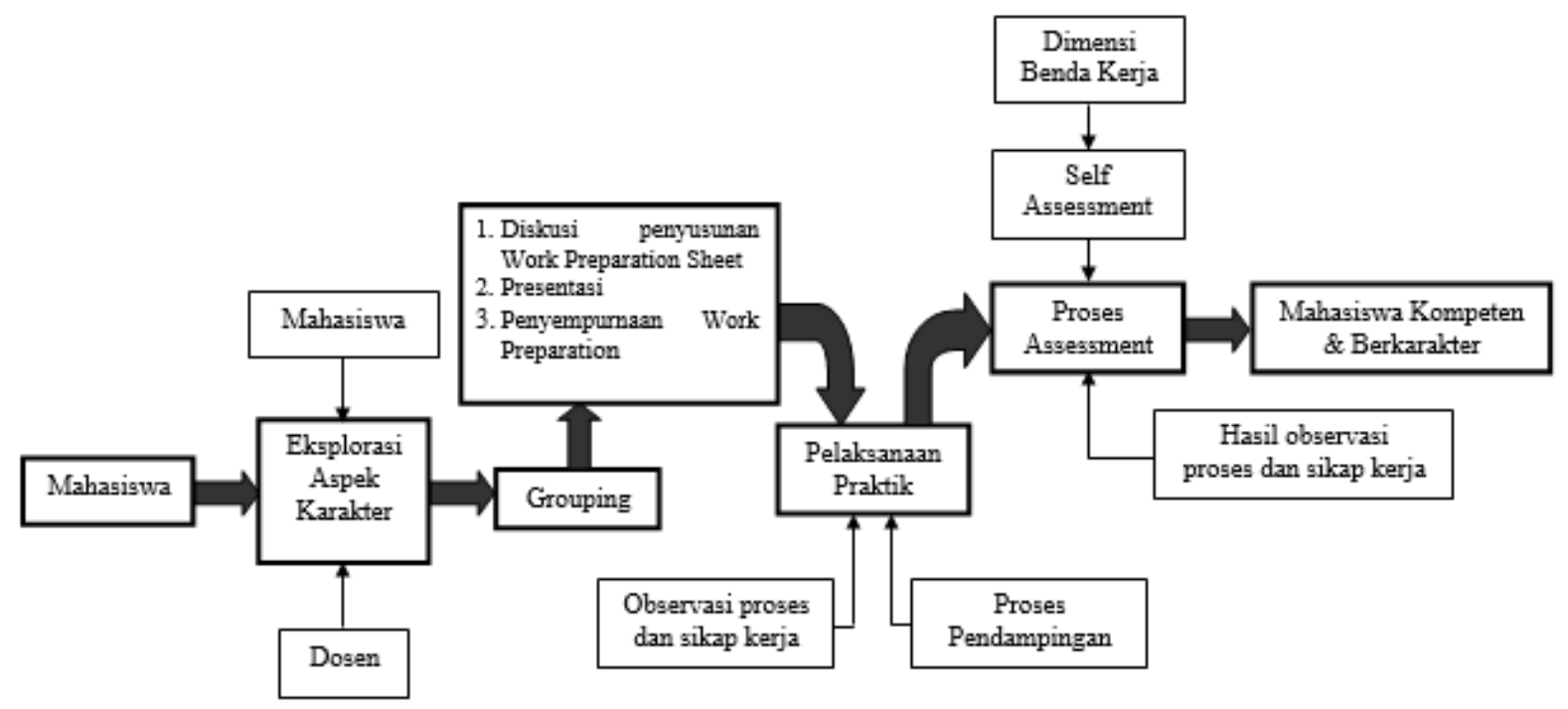

Gambar 1. Tahapan Proses Pembelajaran CBT Berbasis Karakter 
Keterangan tahapan model pembelajaran CBT berbasis Karakter:

Input atau masukan adalah mahasiswa atau dapat juga siswa SMK yang akan mengikuti pembelajaran praktik pemesinan. Model pembelajaran ini dapat diterapkan dalam setiap pembelajaran praktik pemesinan tanpa membedakan tingkat atau semester berapa.

Eksplorasi nilai karakter. Tahapan selanjutnya adalah proses eksplorasi nilai karakter disesuaikan dengan karakter kerja pemesinan, yaitu kemampuan membaca gambar kerja, memilih alat kerja dengan cerdas, menentukan langkah/prosedur kerja, menentukan kriteria kerja, menggunakan alat kerja dengan terampil, merawat alat kerja, menjaga sikap kerja, menjaga lingkungan kerja, mentaati keselamatan kerja, disiplin kerja, mampu sebagai tim kerja, kepatuhan akan peraturan kerja. Pada proses eksplorasi ini dilaksanakan dengan metode diskusi, dimana mahasiswa diminta untuk mengidentifikasi aspek atau nilai karakter apa saja yang harus dijalankan bilamana mereka melaksanakan praktik pemesinan. Hal ini dimaksudkan apabila mahasiswa sudah mampu menggali atau mengidentifikasi nilai karakter, maka tentunya mereka telah memiliki kesadaran untuk melaksanakan nilai-nilai karakter tersebut dalam proses pembelajaran praktik. Dengan demikian apabila mahasiswa melaksanakan praktik dengan prosedur yang benar, sehingga dengan sendirinya mahasiswa tersebut telah melaksanakan nilai karakter. Pada tahapan ini, peran dosen adalah membantu mengarahkan dan menjelaskan setiap nilai karakter yang dapatdiintegrasikan dalam pembelajaran praktik pemesinan.

Grouping. Pembentukan grup dilaksanakan oleh dosen dengan keanggotaan kelompok diambil secara acak. Grup dibentuk agar mahasiswa saling bekerjasama terutama dalam proses penyusunan Work Preparation Sheet (lembar perencanaan kerja). Maksud pembentukan grup ini adalah mambiasakan mahasiswa untuk memiliki rasa toleran dan kerja sama. Setelah dibentuk kelompok, maka dosen dapat membagi job kerja masing-masing kelompok, untuk selanjutnya dipelajari terlebih dahulu oleh mahasiswa, kemudian disusun Work Preparation Sheet.

Penyusunan WPS. Sebelum melaksanakan praktik, maka setiap mahasiswa diwajibkan menyusun Work Preparation Sheet (WPS) atau lembar perencanaan kerja dari setiap job praktik. Secara umum WPS berisikan urutan langkah kerja, alat dan mesin yang digunakan, perhitungan parameter pemotongan, prediksi waktu pekerjaan, alat dan tindakan keselamatan kerja. Dalam hal ini, WPS disusun secara berkelompok dengan harapan mahasiswa mampu bekerjasama dalam tim. WPS harus disusun secara runtut dan benar, sehingga mampu menjadi pedoman mahasiswa dalam melaksanakan praktik. Setelah WPS selesai disusun oleh setiap kelompok, kemudian dipresentasikan dalam kelas sehingga kelompok lain dapat memberikan masukan terhadap WPS yang dipresentasikan oleh kelompok lain tersebut. Dalam tahapan ini dosen berperan sebagai fasilitator dalam diskusi yang dilaksanakan dan bersama mahasiswa menyempurnakan WPS yang mereka susun. Dalam tahapan ini nilai karakter yang diintegrasikan adalah mampu bekerja sama dalam tim, berani mengungkapkan pendapat, dan toleransi.

Pelaksanaan Pembelajaran Praktik. Tahapan selanjutnya adalah masuk dalam pembelajaran praktik. Seluruh mahasiswa melaksanakan praktik dengan berpedoman pada langkah kerja atau prosedur kerja sesuai dengan WPS yang telah disusun. Sebagai salah satu alternatif job yang dapat dipraktikan adalah job yang bersifat collaborative skill, artinya sebuah job praktik yang terdiri dari beberapa komponen yang kemudian dipasangkan satu dengan lainnya. Sehingga job ini dapat dikerjakan secara berkelompok dimana setiap mahasiswa mendapatkan tugas 
untuk mengerjakan satu komponen. Dalam hal ini disamping mahasiswa harus bekerja sama, juga harus memiliki rasa untuk saling menyesuaikan atau toleransi sehingga komponen yang mereka kerjakan dapat dipasangkan dengan baik menjadi satu unit alat. Dalam pelaksanaan kegiatan praktik ini, dapat diamati proses kerja mahasiswa dan proses integrasi nilai karakter yang dilaksanakan oleh setiap mahasiswa dengan menggunakan lembar observasi. Peran dosen dalam kegiatan praktik adalah selalu memberi pembimbingan dan pendampingan, sehingga mahasiswa segera mendapatkan solusi apabila mereka menemui kendala dalam melaksanakan praktik.

Proses Assessment. Tahapan terakhir adalah proses assessment, yang dalam hal ini terdiri dari beberapa komponen penilaian, yaitu penilaian proses kerja, dimensi benda kerja dan hasil pengamatan aspek karakter mahasiswa. Untuk menanamkan rasa kejujuran pada mahasiswa, maka proses assessment dilakukan secara self assessment yaitu mahasiswa dipersilahkan memberikan point pengukuran terhadap dimensi benda kerja yang telah dikerjakan dengan menggunakan lembar assessment. Meskipun demikian dosen juga melakukan pengukuran terhadap dimensi benda kerja yang telah dikerjakan mahasiswa, sehingga dapat mengecek kebenaran dari pengukuran yang telah dilakukan oleh mahasiswa. Kemudian dosen memberikan penilaian atas hasil pembelajaran praktik mahasiswa.

Permasalahan yang ingin dijawab dan dibahas adalah (1) perbedaan aktivitas belajar mahasiswa antara kelas yang menerapkan model pembelajaran CBT berbasis karakter dengan kelas yang tidak menerapkan. (2) perbedaan prestasi belajar mahasiswa antara kelas yang menerapkan model pembelajaran CBT berbasis karakter dengan kelas yang tidak menerapkan .

\section{METODE}

Kegiatan implementasi model pembelajaran CBT berbasis karakter ini dilakukan dengan menggunakan desain ekperimen semu atau Quasi Experimental Design dua kelompok. Populasi dalam penelitian ini adalah mahasiswa semester 3 yang mengikuti mata kuliah Proses Pemesinan Frais, yang berjumlah 4 kelas dengan rincian untuk program S1 berjumlah 2 kelas dan program D3 berjumlah 2 kelas. Sampel penelitian diambil secara Cluster Sampling, yaitu untuk program S1 diambil 1 kelas sebagai kelas kontrol dan program D3 diambil 1 kelas sebagai kelas eksperimen. Penentuan kelas yang diambil sebagai sampel ditentukan/diambil secara random. Meskipun berbeda program, namun sampel yang ditentukan tersebut bersifat homogen, sebab antara program S1 dan D3 pada kenyataannya tidak ada perbedaan dalam materi perkuliahan khususnya pada mata kuliah praktik pemesinan, sehingga asumsinya kemampuannya sama.

Pengumpulan data dalam penelitian ini menggunakan teknik observasi. Instrumen dalam penelitian ini terdiri atas dua jenis instrumen. Pertama, instrumen yang digunakan untuk mengamati sikap dan perilaku kerja mahasiswa selama pembelajaran praktik. Kedua, instrumen yang digunakan untuk mengukur produk/hasil kerja sebagai data prestasi mahasiswa.

Metode atau teknik analisis data yang akan digunakan pada penelitian ini adalah teknik analisis deskriptif kuantitatif. Untuk mengetahui perbedaan capaian antara kelas eksperimen dan kelas kontrol dilakukan uji beda dengan menggunakan teknik uji-t.

\section{HASIL DAN PEMBAHASAN}

Penelitian ini dilaksanakan pada mata kuliah praktik Pemesinan Frais. Proses penelitian dilaksanakan selama 8 pertemuan dan setiap pertemuan diamati perkembangan aktivitas mahasiswa terkait dengan penerapan aspek karakter. Sesuai dengan karakteristik 
mata pelajaran praktik pemesinan, maka aspek karakter yang diintegrasikan adalah jujur, disiplin, tekun/kerja keras, mandiri dan peduli.

Prosedur pelaksanaan implementasi pembelajaran CBT berbasis karakter adalah sebagai berikut:

Pertemuan I. Kegiatan awal dosen menjelaskan tentang rencana kegiatan secara umum. Selanjutnya menjelaskan pengertian aspek karakter dan arti penting aspek karakter dikaitkan dengan karakter kerja praktik pemesinan. Dosen membentuk kelompok mahasiswa menjadi 4 kelompok dengan anggota kelompok ditentukan secara acak. Dosen memimpin diskusi dengan tujuan untuk eksplorasi aspek karakter menurut pendapat mahasiswa.

Pertemuan II. Dosen menjelaskan kegiatan pembelajaran pada pertemuan ini sekaligus membagi job praktik yang akan dikerjakan mahasiswa. Selanjutnya memberikan penguatan terhadap hasil eksplorasi aspek karakter yang telah terlaksana. Dosen menjelaskan tentang pembuatan work preparation sheet (WPS) dari setiap job praktik. Dosen mempersilahkan mahasiswa berdiskusi dalam kelompoknya untuk menyusun WPS terhadap job praktik yang akan dikerjakan. Selanjutnya dosen memimpin diskusi untuk memaparkan WPS yang telah disusun untuk kemudian disempurnakan secara bersama-sama.

Pertemuan III dan seterusnya. Dosen mempersilahkan mahasiswa untuk bekerja sesuai dengan job masing-masing, dengan selalu berpedoman pada WPS yang telah disusun. Dilakukan pengamatan terhadap aktivitas mahasiswa selama praktik. Kepada mahasiswa yang sudah selesai mengerjakan job praktiknya, maka diminta untuk melakukan self assessment dengan dipantau oleh Dosen. Selanjutnya dosen memberikan penilaian terhadap benda kerja yang telah diselesaikan tersebut.
Jumlah mahasiswa kelas eksperimen sebanyak 16 orang dan kelas kontrol sebanyak 18 orang. Data hasil observasi terhadap tingkah laku atau aktivitas mahasiswa terkait dengan penerapan aspek karakter pada kelas eksperimen, dapat dilihat dalam Tabel 1.

Tabel 1. Aktivitas mahasiswa kelas eksperimen

\begin{tabular}{lcccccc}
\hline \multirow{2}{*}{$\begin{array}{c}\text { Aspek } \\
\text { karakter }\end{array}$} & \multicolumn{6}{c}{ Jumlah siswa pada pertemuan } \\
\cline { 2 - 7 } & 3 & 4 & 5 & 6 & 7 & 8 \\
\hline Jujur & - & 11 & 12 & 13 & 16 & 16 \\
Disiplin & 10 & 13 & 15 & 14 & 16 & 16 \\
Tekun/Kerja & 8 & 11 & 12 & 12 & 15 & 16 \\
Keras & & & & & & \\
Mandiri & 6 & 10 & 13 & 13 & 14 & 16 \\
Peduli & 11 & 13 & 14 & 15 & 14 & 15 \\
\hline
\end{tabular}

Sedangkan data hasil observasi terhadap tingkah laku atau aktivitas mahasiswa terkait dengan penerapan aspek karakter pada kelas kontrol, dapat dilihat dalam Tabel 2.

Tabel 2. Aktivitas mahasiswa kelas kontrol

\begin{tabular}{lcccccc}
\hline \multirow{2}{*}{$\begin{array}{c}\text { Aspek } \\
\text { karakter }\end{array}$} & \multicolumn{6}{c}{ Jumlah siswa pada pertemuan } \\
\cline { 2 - 7 } & 3 & 4 & 5 & 6 & 7 & 8 \\
\hline Jujur & - & 5 & 7 & 9 & 12 & 13 \\
Disiplin & 5 & 8 & 9 & 11 & 10 & 12 \\
Tekun/Kerja & 4 & 5 & 6 & 6 & 8 & 11 \\
Keras & & & & & & \\
Mandiri & 5 & 6 & 5 & 7 & 7 & 10 \\
Peduli & 4 & 6 & 6 & 9 & 11 & 13 \\
\hline
\end{tabular}

Berdasarkan hasil uji beda didapatkan nilai $\mathrm{t}$ hitung $=5,603$, sedangkan nilai $t$ table adalah 2,178 dengan signifikansi $0,000<p$ $(0,05)$. Karenathitung $>$ ttabel, maka $H_{0}$ ditolak. Sehingga terbukti bahwa terdapat perbedaaan aktivitas mahasiswa antara kelas eksperimen dengan kelas kontrol. Dimana aktivitas mahasiswa kelas eksperimen lebih baik dari kelas kontrol.

Data kecepatan kerja praktik dan prestasi yang dicapai mahasiswa pada kelas eksperimen, dapat dilihat dalam Tabel 3. 
Tabel 3. Kecepatan kerja dan prestasi mahasiswa kelas eksperimen

\begin{tabular}{ccc}
\hline Pertemuan & $\begin{array}{c}\text { Jumlah Job } \\
\text { yang selesai }\end{array}$ & $\begin{array}{c}\text { Nilai rata- } \\
\text { rata }\end{array}$ \\
\hline 4 & 1 & 85 \\
6 & 3 & 85 \\
8 & 4 & 86 \\
\hline
\end{tabular}

Sedangkan data kecepatan kerja praktik dan prestasi yang dicapai mahasiswa pada kelas kontrol, dapat dilihat dalam Tabel 4.

Tabel 4. Kecepatan kerja dan prestasi mahasiswa kelas kontrol

\begin{tabular}{ccc}
\hline Pertemuan & $\begin{array}{c}\text { Jumlah Job } \\
\text { yang selesai }\end{array}$ & $\begin{array}{c}\text { Nilai rata- } \\
\text { rata }\end{array}$ \\
\hline 4 & - & 76 \\
6 & 1 & 76 \\
8 & 2 & 78 \\
\hline
\end{tabular}

Berdasarkan hasil uji beda, didapatkan nilai t hitung $=4,358$, sedangkan, nilai $t$ table adalah 2,039 dengan signifikansi $0,000<p$ $(0,05)$. Karena thitung $>$ tabel, maka $H_{0}$ ditolak. Sehingga terbukti bahwa terdapat perbedaaan prestasi belajar siswa antara kelas eksperimen dengan kelas kontrol. Dimana prestasi belajar mahasiswa kelas eksperimen lebih baik dari kelas kontrol.

Penerapan model pembelajaran CBT berbasis karakter dalam pembelajaran praktik pemesinan Frais, bertujuan untuk mengatasi permasalahan pembelajaran terkait dengan sikap mahasiswa selama pembelajaran dan permasalahan terkait dengan prestasi yang dicapai oleh mahasiswa, kususnya pada pembelajaran praktik pemesinan Frais. Harapannya setelah menerapkan model pembelajaran ini, mahasiswa akan menguasai kompetensi praktik pemesinan Frais dengan maksimal dan memiliki karakter yang unggul, yang ditunjukan dengan sikap dan perilaku yang baik.

Proses penelitian ini, penerapan dilakukan terhadap satu kelas sebagai kelas eksperimen, dan sebagai pembanding diambil satu kelas sebagai kelas kontrol yang tidak menerapkan model pembelajaran ini. Aspek/nilai karakter yang dapat diamati dalam pembelajaran ini, disesuaikan dengan karakter kerja proses pemesinan, yaitu jujur, disiplin, tekun/kerja keras, mandiri dan peduli. Jujur bisa diamati dari proses self assessment, apakah mahasiswa betul-betul menuliskan hasil pengukuran sesuai dengan kondisi benda kerja yang mereka hasilkan atau tidak. Untuk mengetahui haltersebut, maka dosen melakukan cross chek terhadap dimensi benda kerja yang dihasilkan oleh mahasiswa. Disiplin bisa diamati pada saat kedatangan mahasiswa tepat waktu apa tidak, kemudian selama proses pembelajaran mahasiswa menaati semua prosedur atau tahapan pembelajaran apa tidak termasuk dalam pemakaian alat dan mesin. Tekun/kerja keras dapat diamati dari selama proses pembelajaran, mahasiswa fokus bekerja apa tidak. Mandiri dapat diamati dari tingkat kemandirian mahasiswa dalam melaksanakan pembelajaran praktik di bengkel. Peduli dapat diamati pada saat proses cleaning atau pembersihan mesin dan tempat praktik.

Berdasarkan hasil penelitian yang didapatkan, untuk pelaksanaan aspek karakter, pada kelas eksperimen pada pertemuan ke 8, tampak bahwa seluruh mahasiswa yang berjumlah 16 orang telah melaksanakan aspek karakter, kecuali pada aspek mandiri dilaksanakan oleh 15 orang. Dan bila dipersentase, sebanyak 98,75\% mahasiswa telah melaksanakan aspek karakter. Namun pada kelas kontrol, pelaksanaan aspek karakter baru dilaksanakan oleh terbanyak 13 mahasiswa saja. Bila dipersentase, pelaksanaan aspek karakter pada kelas kontrol sebesar 73,75\%. Kemudian untuk membuktikan adanya perbedaan pelaksanaan aspek karakter atau aktivitas mahasiswa selama pembelajaran antara kelas eksperimen dan kelas kontrol, dilakukan dengan uji beda dengan menggunakan teknik uji t. Dari pelaksanaan uji t didapatkan nilai t hitung $=5,603$, sedangkan nilai $t$ table adalah 2,178 dengan signifikansi $0,000<p(0,05)$. Karenathitung $>$ ttabel, maka $\mathrm{HO}_{\mathrm{O}}$ ditolak. Sehingga terbukti bahwa terdapat perbedaaan aktivitas mahasiswa antara kelas eksperimen dengan kelas kontrol. Dimana 
aktivitas mahasiswa kelas eksperimen lebih baik dari kelas kontrol.

Dalam penelitian ini juga diamati tentang prestasi mahasiswa. Pada kelas eksperimen didapatkan data bahwa hingga pertemuan ke delapan rata-rata nilai yang didapatkan sebesar 85,33. Sedangkan untuk kelas kontrol pada pertemuan ke delapan, nilai rata-rata yang diraih oleh mahasiswa sebesar 76,67. Untuk membuktikan adanya perbedaan prestasi yang diraih oleh kelas eksperimen dan kelas control, maka dilakukan uji beda dengan menggunakan teknik uji t. Berdasarkan hasil uji beda, didapatkan nilai t hitung $=4,358$, sedangkan, nilai $t$ table adalah 2,039 dengan signifikansi $\quad 0,000<p \quad(0,05) . \quad$ Karena thitung $>$ tabel, maka $\mathrm{H}_{0}$ ditolak. Sehingga terbukti bahwa terdapat perbedaaan prestasi belajar siswa antara kelas eksperimen dengan kelas kontrol. Dimana prestasi belajar mahasiswa kelas eksperimen lebih baik dari kelas kontrol.

Untuk memperkuat hasil penelitian, maka diamati juga kecepatan kerja mahasiswa antara kelas eksperimen dan kelas kontrol. Hingga pertemuan ke delapan, kecepatan kerja mahasiswa pada kelas eksperimen telah mampu menyelesaikan hingga 4 job praktik. Sedangkan untuk kelas kontrol, pada pertemuan ke delapan baru mampu menyelesaikan 2 job praktik. Berdasarkan data tersebut tampak jelas bahwa kecepatan kerja untuk kelas eksperimen lebih cepat dari kelas kontrol.

\section{SIMPULAN}

Berdasarkan hasil penelitian yang telah didapatkan, maka dapat diambil beberapa kesimpulan sebagai yaitu terdapat perbedaan aktivitas belajar mahasiswa dalam pembelajaran praktik Pemesinan Frais melalui penerapan model pembelajaran CBT berbasis karakter, dimana aktivitas belajar mahasiswa pada kelas eksperimen lebih baik dari kelas kontrol.Terdapat perbedaan prestasi belajar mahasiswa dalam pembelajaran praktik Pemesinan Frais melalui penerapan model pembelajaran CBT berbasis karakter, dimana prestasi belajar pada kelas eksperimen lebih baik dari kelas kontrol.

\section{DAFTAR RUJUKAN}

Badan Pusat Statistik. (2014). Keadaan Ketenagakerjaan Indonesia Agustus 2017. www.bps.go.id. Diakses pada 11 Desember 2014 pukul 12.30.

Gonczi, A. (1998). Developing a competent workforce: Adult training strategies for vocational educators and trainers. Leadbrook SA: National Centre for Vocational Education Research Ltd.

Mulyasa, E. (2006). Kurikulum Berbasis Kompetensi. Bandung: Remaja Rosdakarya.

Paryanto, dkk. (2013). Pengembangan Model Pembelajaran Competence Based Training (CBT) pada Pemesinan Frais di FT UNY. Laporan Penelitian.

Pemerintah Republik Indonesia.(2003). Undang-Undang No 20 Tahun 2003 Tentang Sistem Pendidikan Nasional

Sidik Purnomo. (2009). Prinsip Pembelajaran Berbasis Kompetensi . Diambil dari http://kidispur.blogspot.com/prinsippembelajaran-berbasis.html, pada tanggal 22 April 2009.

Suyanto. (2010). Urgensi Pendidikan Karakter. Diambil dari: http://waskitamandiribk.wordpress.co $\mathrm{m}$ 